\title{
INVESTIGATION OF BALLISTIC RESISTANCE OF ADHESIVE BONDED MULTI-LAYER STRUCTURES
}

\author{
BADANIA ODPORNOŚCI NA PRZEBICIE \\ KLEJONYCH STRUKTUR WIELOWARSTWOWYCH*
}

\begin{abstract}
The aim of the study was to evaluate the possibility of using multilayer structures for light armour, in which the elements of the ceramic type $\mathrm{SiC}$ and $\mathrm{Al}_{2} \mathrm{O}_{3}$ were bonding by adhesive joins with antiballistic polyethylene and aramid fabrics. Ballistic resistance shells was determined using for this purpose the test stand constructed on the basis of helium gun and high-speed camera. It has been shown that the laminated structure composed of thin metal layers and aramid fabrics as well as polymer composites made of aramid fabric has lower ballistic resistance than loose fabric packs. It was also demonstrated the functionality of the use of the ceramic component as a separate package, which the ceramic plates are adhesive bonded between the two layers of sheet metal. There is also evidence that fabrics composed of thin layers of material poorly connected with each other, should not be adhesively bonded to the ceramic. It proposed the preparation of specimens, which best reconstruct the load of ceramic plates adhesive bonded to fabric, which are made of lightweight bulletproof vests and ballistic panels.
\end{abstract}

Keywords: adhesive joint, multi-layer materials, light-weight ballistic armour.

Celem badań była ocena możliwości zastosowania opracowanych struktur wielowarstwowych do wytwarzania lekkich pancerzy, mogących znaleźć zastosowanie jako kuloodporne osłony balistyczne śmigłowców bojowych i innego lekkiego sprzętu wojsko-

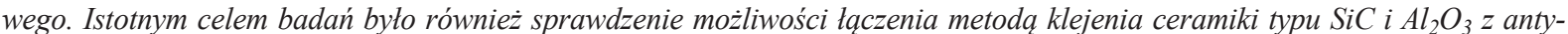
balistycznymi tkaninami polietylenowymi i aramidowymi. Odporność na przebicie była badana z wykorzystaniem stanowiska z działem helowym i ultraszybka kamerą. W wyniku przeprowadzonych badań stwierdzono, iż pakiety luźnych tkanin aramidowych charakteryzuje większa odporność na przebicie w porównaniu z kompozytami polimerowymi wytworzonymi z takich tkanin oraz kompozytami warstwowymi złożonymi z cienkich warstw metalowych i tkanin aramidowych. Ponadto zauważono, że warstwy ceramiczne znacznie zwiększaja odporność na przebicie oston balistycznych i ich stosowanie w takich osłonach wydaje się niezbędne oraz, że wklejenie ptytek ceramicznych pomiędzy dwie cienkie blachy ze stopu aluminium i nie łączenie ich bezpośrednio z tkaninami aramidowymi zapewnia w przypadku uderzenia pociskiem zniszczenie małej powierzchni warstwy ceramicznej, a więc w małym stopniu zmniejsza wtaściwości ochronne ostony.

Slowa kluczowe: połaczenie klejowe, materiat wielowarstwowy, lekka ostona balistyczna.

\section{Introduction}

Contemporary light ballistic shields are usually multilayered structures of low density [2, 6, 9, 10]. In the past, the shield used to be a monolithic plate made with high strength steels or titanium alloys. Recently it have been observed a prevailing tendency to use shields which ensure the best possible ballistic protection with the lowest possible mass, at the same time. In order to achieve the abovementioned effect, manufacturers use multilayer structures, made with various materials. The external part, usually of high strength and of proper hardness (e.g. a layer of ceramics) should be able to withhold or at least deform a penetrator (bullet), which facilitates its "capture" and ensures protection against further perforation of the external layers, most commonly composed of products based on aramid or polythene fibres. Ceramic layers of light ballistic shields are commonly produced with Aluminium oxide $\left(\mathrm{Al}_{2} \mathrm{O}_{3}\right)$, Silicon carbide $(\mathrm{SiC})$ and Boron carbide $\left(\mathrm{B}_{4} \mathrm{C}\right)[6,8]$. There is also a large number of investigations over the application of Silicon nitride $\left(\mathrm{Si}_{3} \mathrm{~N}_{4}\right)$, Titanium boride $\left(\mathrm{TiB}_{2}\right)$, Aluminium nitride $(\mathrm{AlN})$, sialons $(\mathrm{SiAlON})$, glasses $[4,6]$, and ceramic composites reinforced with metal or intermetallic phases [3]. Ceramic layers are most often joined with other layers absorbing the energy, by the adhesive bonding method [1]. In literature the stress is put on the role of adhesive joints in the shaping of protective properties of multilayer armours $[5,7]$. For instance the research [7] indicated that for a twin-layer amour (Aluminium oxide/aluminium), there is an optimum thickness of the adhesive layer $(0.3 \mathrm{~mm})$, where the effectiveness of the armour is the highest. The most commonly used adhesives are cyanoacrylic ones or adhesives based on epoxide resins.

The aim of this investigation is to assess the possibilities of applying the designed multilayer structures for the manufacture of light armour which may be exploited as bulletproof ballistic shields of combat helicopters and other light military equipment. A crucial part of the investigation is also to check the possibilities of bonding $\mathrm{SiC}$ and $\mathrm{Al}_{2} \mathrm{O}_{3}$ type ceramics with anti-ballistic polythene and aramid fabrics, by means of the adhesive bonding method.

(*) Tekst artykułu w polskiej wersji językowej dostępny w elektronicznym wydaniu kwartalnika na stronie www.ein.org.pl 


\section{Methods}

\subsection{Ballistic resistance of multi-layer structures - object and method of investigation}

While taking into account low density of the tested multilayere armours, it was decided that they will be made on the basis of aluminium alloy sheets AW $2024 \mathrm{~T} 3$ and four aramid fabrics, which differ in their structure and basis weight $\left(\mathrm{g} / \mathrm{m}^{2}\right)$. Moreover, an investigation are conducted, where the composites were protected by the ceramic layer, prepared on the basis of Silicon carbide $\mathrm{SiC}$.

In order to prepare the specimens, $0.3 \mathrm{~mm}$ thick aluminium alloy sheets are used as well as aramid fabrics Microflex, CT 709, T 750 and XPS102. The ceramic layer was composed of plates, whose shape was the right prism, and the base was a regular hexagon (the length of the inscribed circle equalled $20.2 \mathrm{~mm}$ and the height was $4.2 \mathrm{~mm}$ ). An epoxy adhesive Epidian 57 is used, cured by Z1 curing agent to prepare the adhesive bonding structures. The fact that the adhesive is used and not saturant is connected with the fact that the exploited fabrics, in practice, cannot be oversaturated. Moreover, the saturants used for oversaturating the fabrics are characterized with worse adhesion to metals, compared to adhesives.

The surfaces of the aluminium alloy sheets were prepared for bonding by rubbing with an abrasive cloth of granulation 80 and rinsing with extraction gasoline. The attempts of sanding thin aluminium sheets resulted in plastic deformations, which caused that the whole surface could not be bonded. The adhesive layers of the specimens were initially cured in ambient temperature, with the pressure equalling $0.05 \mathrm{MPa}$ for 24 hours, and then for 6 hours at the temperature of $60^{\circ} \mathrm{C}$. The specimens of $150 \times 250 \mathrm{~mm}$, prepared in such a way, were later used for cutting specimens with the "water jet" method. The specimens' shape enabled to fix them in a special gripping frame (Fig. 1), placed directly opposite a helium gas gun (Fig. 1). The ballistic resistance was tested by shooting at the specimens with steel bullets of $8 \mathrm{~mm}$ in diameter. During the firing at composite specimens, the trajectory of the bullets was registering by means of a camera for fast-changing phenomena (Phantom v12). The scope of the camera's observation was set in such a way that it covered both the space in

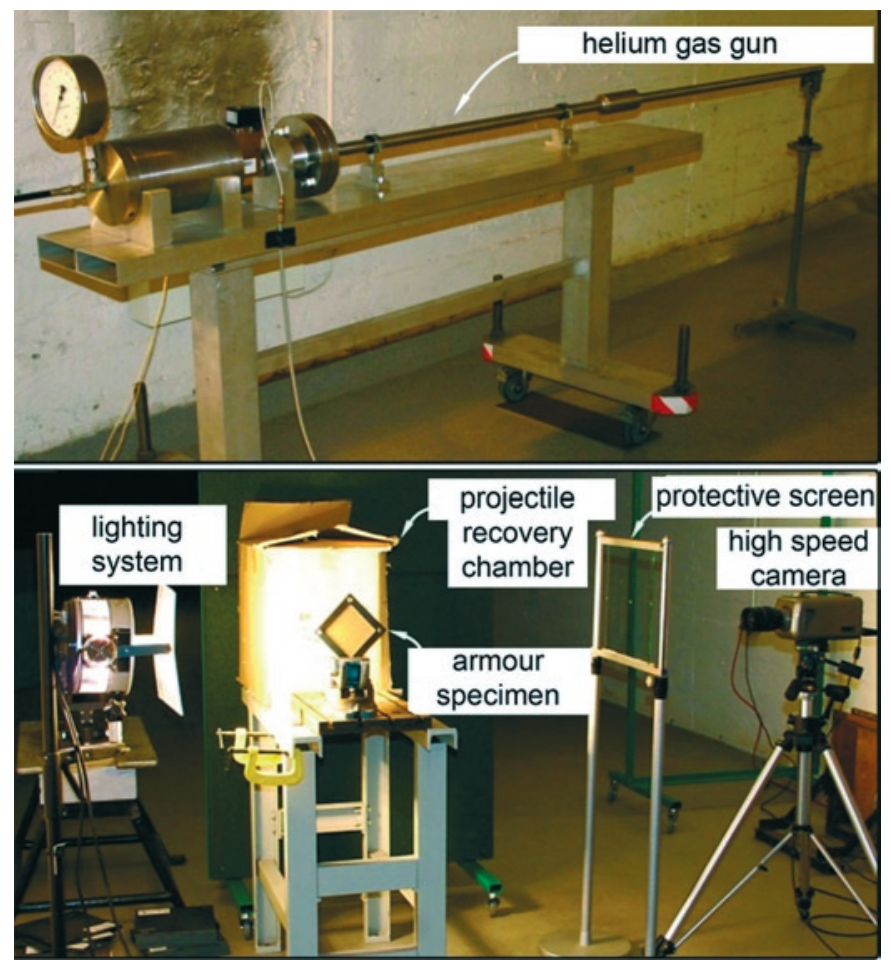

Fig.1. The experimental stand for testing ballistic perforation resistance

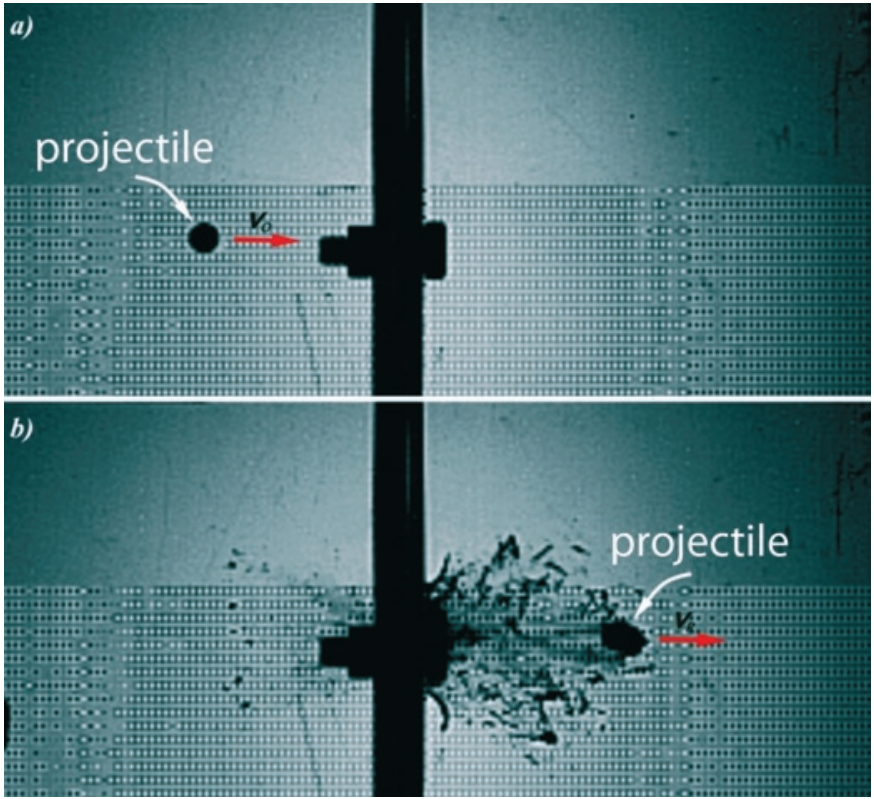

Fig. 2. Observation area of a high speed camera: view of a spherical projectile and an armour specimen before (a) and after (b) impact

front of and behind the multilayer shield (Fig. 2). Due to such a configuration of the camera, it was possible to obtain experimental data, which later served to calculate the speed of the bullet before hitting and after puncture. For the measurement of ballistic resistance, the value of the energy absorbed by the shield during its penetration is accepted, in short absorbing energy $E_{\mathrm{a}}$ - the difference of kinetic energies of the bullet before hitting and after puncture the shield specimen. The energy of puncture (absorbing energy) was referred to the thickness of the pack and the basis weight of the tested materials. Moreover, ballistic resistance of the selected specimens we with use a Parabellum bullet were conducted.

\subsection{Results and discussion}

The composite panels were prepared as aramid-epoxy composites, where the seven layers of the aramid fibre were bonded with the Epidian 57/Z1 adhesive. On the basis of the prepared composite panels, specimens were prepared for ballistic testing. In addition, the specimen was made, consisting of 7 layers of XPS102 fabric, however the fabric layers were not adhesive bonding but stitched together on the edges. The test results are specified in Table 1.

Among the three tested fabrics, the XPS102 fabric is characterized with the best protective properties. The absorbing energy of loose XPS102 fabrics (stitch together on the edge of the specimen) almost doubled the absorbing energy of the laminate, made with this fabric.

The research also is conducted into FML (Fibre Metal Laminates), consisting of alternate layers of thin metal sheets (8 layers) and aramid fabrics (7 layers), adhesive bonding with Epidian 57/Z1. The test results are specified in Table 2.

The absorbing energy, in relation to the basis weight of the tested FML, in each case, proved to be lower than the absorbing energy of the laminates.

Another stage of the research was connected with testing FML materials, which had one layer of $\mathrm{SiC}$ ceramics adhesive bonded, shielded with one layer of carbon fibre, oversaturated with Epidian $57 / \mathrm{Z} 1$ adhesive. In this case, the penetrators fired from the helium canon (steel bullets) did not break through the first tested specimens (Table 3). Therefore, the two remaining specimens underwent ballistic testing by Parabellum munitions, whose energy of $490 \mathrm{~J}$, exceeds the energy of steel bullets, hitting the examined materials. As expected, the Parabellum bullets did not pierce the tested composites (Fig. 3). 
Table 1. Ballisic resistance of laminates $(L)$ and loose aramid layers $(7 L)$

\begin{tabular}{|c|c|c|c|c|c|c||}
\hline Material & Thickness [mm] & $\begin{array}{c}\text { Density } \\
{[\mathrm{g} / \mathbf{c m} 3]}\end{array}$ & $\begin{array}{c}\text { Absorbing energy } \\
{[\mathrm{J}]}\end{array}$ & $\begin{array}{c}\text { Energy/thickness } \\
{[\mathbf{J} / \mathbf{m m}]}\end{array}$ & $\begin{array}{c}\text { Basis weight } \\
{\left[\mathbf{k g} / \mathbf{m}^{2}\right]}\end{array}$ & $\begin{array}{c}\text { Energy/ } \\
\text { basis weight }\end{array}$ \\
\hline L XPS102 & 3.90 & 1.18 & 80.49 & 20.64 & 4.60 & 17.49 \\
\hline L Microflex & 2.15 & 1.23 & 39.94 & 18.58 & 2.64 & 15.11 \\
\hline L T750 & 4.10 & 1.05 & 72.71 & 17.73 & 4.30 & 16.89 \\
\hline XPS102-7L & 3.20 & 1.18 & 118.18 & 36.93 & 3.78 & 31.30 \\
\hline
\end{tabular}

Table 2. Ballistic resistance of FML composites on the basis of 202473 alloy and aramid fibres

\begin{tabular}{|c|c|c|c|c|c|c||}
\hline Material & Thickness [mm] & $\begin{array}{c}\text { Density } \\
{\left[\mathbf{g} / \mathbf{c m}^{\mathbf{3}}\right]}\end{array}$ & $\begin{array}{c}\text { Absorbing energy } \\
{[\mathbf{J}]}\end{array}$ & $\begin{array}{c}\text { Energy/thickness } \\
{[\mathbf{J} / \mathbf{m m}]}\end{array}$ & $\begin{array}{c}\text { Basis weight } \\
{\left[\mathbf{k g} / \mathbf{m}^{2}\right]}\end{array}$ & $\begin{array}{c}\text { Energy/ } \\
\text { basis weight }\end{array}$ \\
\hline $\begin{array}{c}\text { FML } \\
\text { CT 709 }\end{array}$ & 4.10 & 2.03 & 100.37 & 24.48 & 8.32 \\
\hline $\begin{array}{c}\text { FML } \\
\text { XPS102 }\end{array}$ & 6.35 & 1.69 & 159.33 & 26.67 & 10.73 & 12.06 \\
\hline $\begin{array}{c}\text { FML } \\
\text { Microflex }\end{array}$ & 4.65 & 1.91 & 112.32 & 24.15 & 8.89 & 12.64 \\
\hline $\begin{array}{c}\text { FML } \\
\text { T 750 }\end{array}$ & 6.79 & 1.69 & 182.17 & 26.83 & 11.48 & 15.88 \\
\hline
\end{tabular}

Table 3. Ballistic resistance of FML composites, on the basis of $2024 \mathrm{T3}$ alloy and aramid fabrics with $\mathrm{Si}_{2} \mathrm{C}$ type ceramics

\begin{tabular}{|c|c|c|c|c|c|c|c|}
\hline Material & $\begin{array}{c}\text { Basis weight } \\
\text { with ceramics } \\
{\left[\mathrm{g} / \mathrm{cm}^{2}\right]}\end{array}$ & $\begin{array}{l}\text { Thickness with } \\
\text { ceramics [mm] }\end{array}$ & $\begin{array}{c}\text { Thickness } \\
{\left[\mathrm{g} / \mathrm{cm}^{3}\right]}\end{array}$ & $\begin{array}{l}\text { Speed } \\
{[\mathrm{m} / \mathrm{s}]}\end{array}$ & $\begin{array}{c}\text { Absorbing energy } \\
{[\mathrm{J}]}\end{array}$ & $\begin{array}{c}\text { Energy/ } \\
\text { thickness } \\
{[\mathrm{J} / \mathrm{mm}]}\end{array}$ & $\begin{array}{c}\text { Energy/ } \\
\text { basis weight }\end{array}$ \\
\hline $\begin{array}{l}\text { FML-C } \\
\text { CT709 }\end{array}$ & 22.80 & 8.75 & 2.61 & 655 & $>448$ & $>51.0$ & $>19.54$ \\
\hline $\begin{array}{c}\text { FML-C } \\
\text { XPS102 }\end{array}$ & 24.55 & 11.00 & 2.23 & 657 & $>451$ & $>41.0$ & $>18.39$ \\
\hline $\begin{array}{c}\text { FML-C } \\
\text { Microflex }\end{array}$ & 23.36 & 9.30 & 2.51 & \multicolumn{2}{|c|}{ lead bullet Parabellum $\sim 490 \mathrm{~J}$} & $>52.7$ & $>20.98$ \\
\hline $\begin{array}{c}\text { FML-C } \\
\text { T750 }\end{array}$ & 25.96 & 11.44 & 2.27 & \multicolumn{2}{|c|}{$\begin{array}{c}\text { lead bullet } \\
\text { Parabellum } \sim 490 \mathrm{~J}\end{array}$} & $>42.8$ & $>18.88$ \\
\hline
\end{tabular}

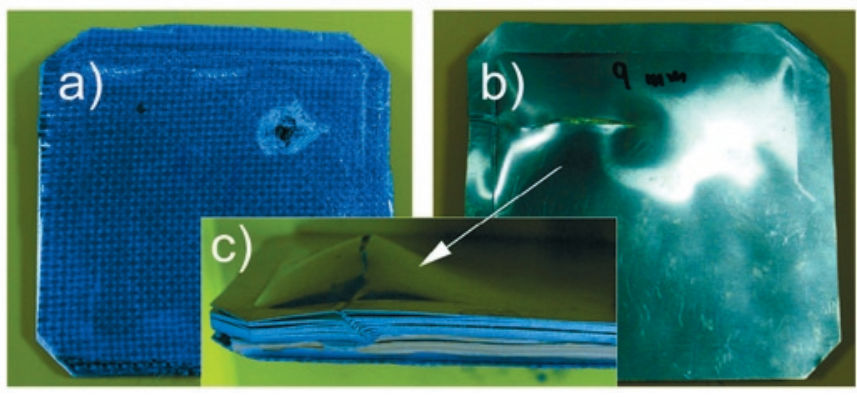

Fig. 3. View of FML-C Microflex specimen after a piercing attempt by a Parabellum bullet: $a$-view from the ceramics side, $b$-deformation and cracking of the last metal layer, $c$-delamination of material

The final stage of the ballistic investigation concerned aramid fabrics, on one side covered by ceramic plates. In the first case, these were seven stitched together layers of CT709 fabric, covered with one layer of $\mathrm{Al}_{2} \mathrm{O}_{3}$ ceramic plates, adhesive bonded between two sheets made with $2024 \mathrm{~T} 3$ alloy, $0.3 \mathrm{~mm}$ thick. In the second case, a polymer composite on the basis of seven layers of T750 fabric and L285 resin was made, which had one layer of $\mathrm{SiC}$ ceramic plates adhesive bonded. The ballistic resistance of shields was checked, prepared in such a way, to piercing by a Parabellum bullet. In both cases, the bullet did not shoot through the specimens (Fig. 4 and 5). The ceramic plates, adhesive bonded directly to the composite made with T750 fabric, with Epidian 57/Z1 adhesive, became separated from the plastically deformed material (Fig. 5). In the case of the plates bonded in between

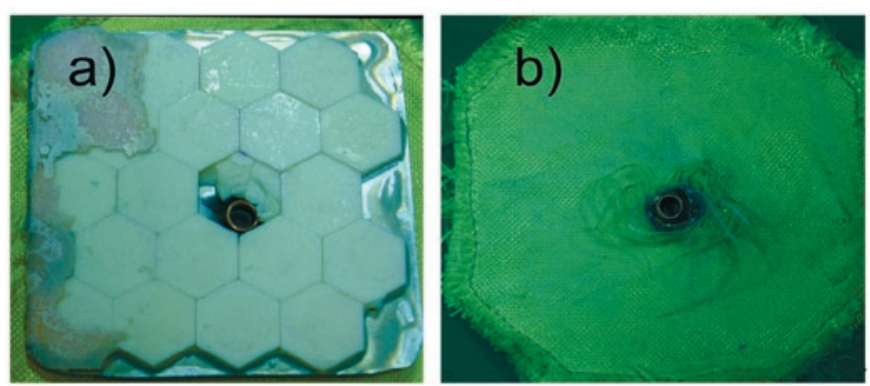

Fig. 4. View of specimen composed of seven stich layers of CT709 fabric and ceramics adhesive bonded between two thin sheets made with $A W$ $2024 T 3$ alloy, after an ballistic attempt with use a Parabellum bullet: a. - view of damaged ceramics $b$. - view of fabric with a stuck bullet

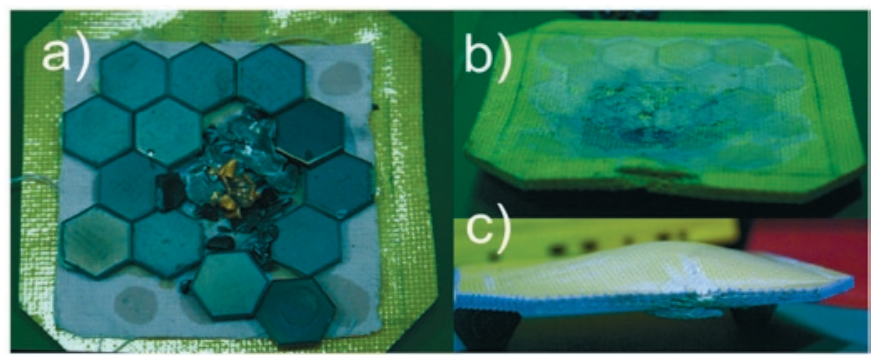

Fig. 5. View of specimen made with T750 fabric composite with a adhesive bonded layer of ceramics, after a ballistic attempt with a Parabellum bullet: $a$. - view from the side of ceramics $b$. - view of composite with marks of the separated ceramics $c$. - permanent deformation of the composite 
two layers of thin aluminium alloy sheets, only one ceramic plate was damaged, whereas the remaining ones, which were still bonded to the sheet, shielded the composite (Fig. 4).

Since the tests proved that the ceramic layers considerably increase ballistic of shields, their use in such shields seems to be necessary. Therefore, it was conducted research which assessed the possibility of adhesive bonding a ceramic layer to antiballistic fabrics.

\subsection{Adhesive bonding of ceramics to fabrics - materials and method of research}

In the research two types of polyethylene fabrics are used, marked as HB50 ROLL 401184C and HB26 ROLL 401400B, four types of aramid fabrics marked as Microflex CT 709, T 750 and XP S102 as well as $\mathrm{Al}_{2} \mathrm{O}_{3}$ and $\mathrm{SiC}$ ceramics.

Taking into account the fact that polyethylene, as thermoplastic component, is characterised with limited adhesion to standard adhesives, the investigation centered around adhesives designed to bond polymer components, including acrylic adhesives: LOCTITE 3038, Scotch-Weld 8010 as well as cyanoacrylate adhesive: BONDICX 01 CX-80, epoxy adhesive: POXIPOL and also silicone adhesives: Professional Black Silicone and Terostat M9399.

Due to lack of norms which refer to specifying the strength of adhesive bonds in materials, which are being investigated, four types of specimens are selected and tested their suitability.

1. The ceramic plate had straps of the selected fabrics bonded on both sides, the straps being $20 \mathrm{~mm}$ width and $70 \mathrm{~mm}$ long. The fabric endings were fixed in the grips of the strength testing machine and the specimen underwent tension. In the test, the distance between the grips was $70 \mathrm{~mm}$. The adhesive joints of such specimens were mainly loaded to peel off (Fig. 6).
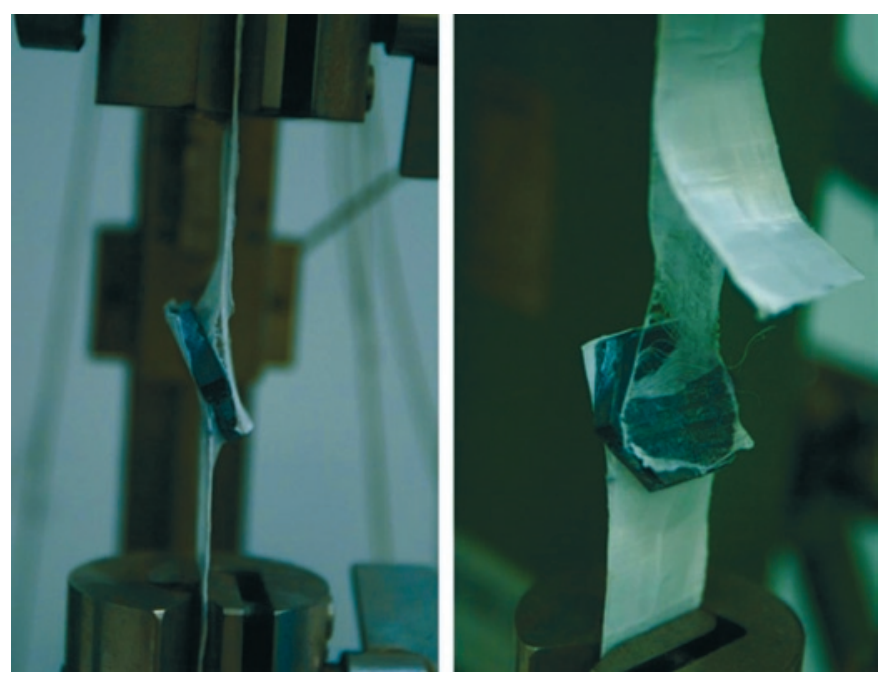

Fig. 6. Manner of fixing specimens no 1

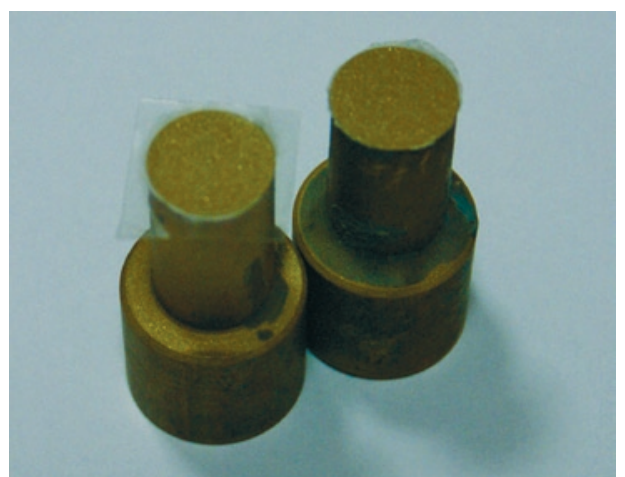

Fig.7. Cylindrical (brass) pieces of the specimen (butt joint) for loading in the tension test.
2. Cylindrical metal elements, front-bonded through a layer of the tested fabric (butt joints) and loaded in the tension test. (Fig.7).

3. The steel cylindrical pieces had ceramic plates bonded with epoxy adhesive Epidian 57/Z1 (Fig. 8). Next the pieces were bonded to the front through a layer of the fabric. In this way butt joints specimens for the testing were prepared and they were next loaded in the tension test.

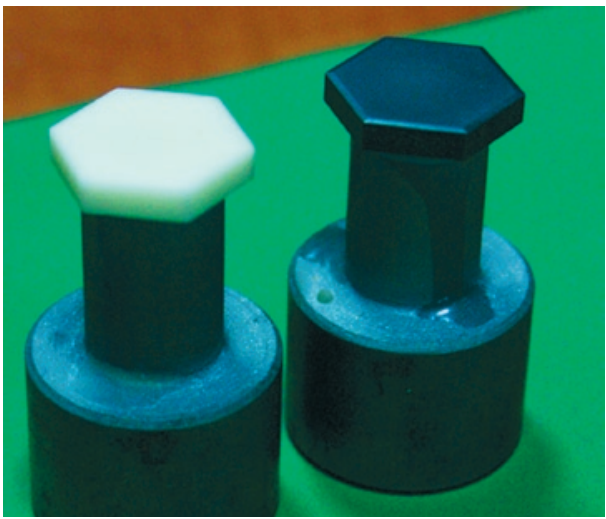

Fig. 8. Steel pieces with bonded ceramic plates

4. In the front sockets of the cylindrical steel specimens had ceramics adhesive bonded (Fig. 9) with Epidian 57/Z1 adhesive. The threaded hole made in the specimen enabled to fix it in the grip of the strength testing machine through a screwed in rod with a tapped thread. The ceramics had fabric straps adhesive bonded, measuring $30 \times 150 \mathrm{~mm}$.

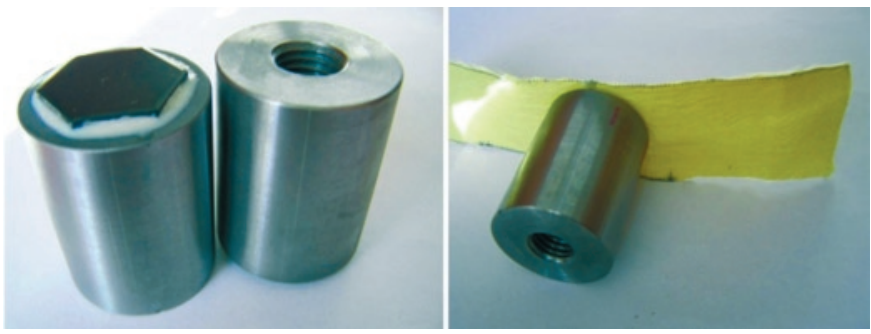

Fig. 9. Specimens with bonded of ceramics and adhesive bonded fabric strap

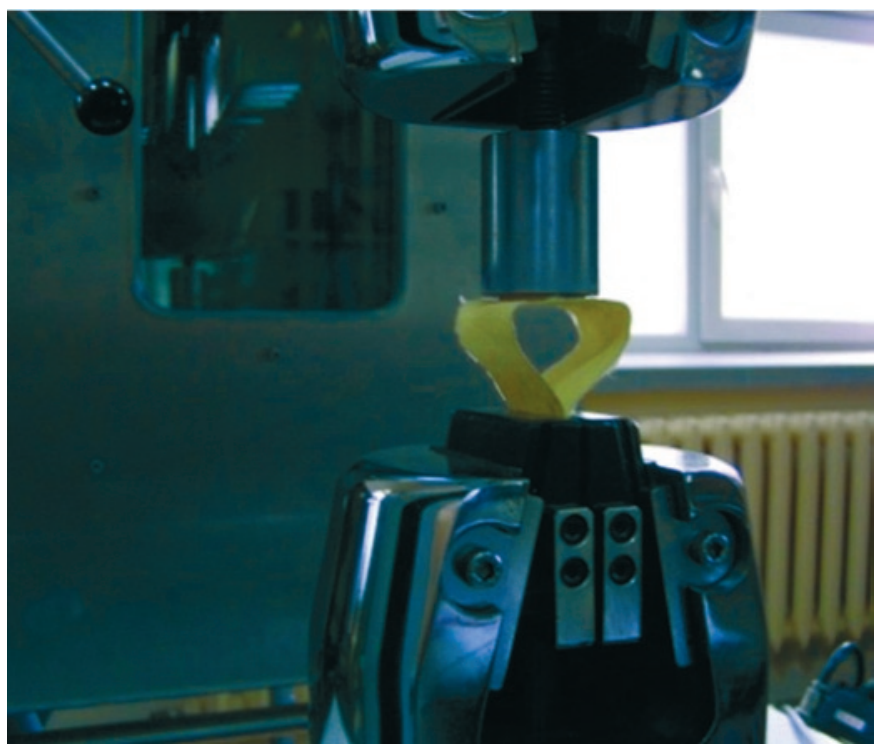

Fig. 10. Specimen fitted in the grips of the strength testing machine 
Table 4. The test results of average breaking load of adhesive bonding of polyethylene fabrics to ceramics by means of Bondicx 01 CX80

\begin{tabular}{|c|c|c|}
\hline \multicolumn{3}{|c|}{ Bondicx 01 CX80 adhesive } \\
\hline \multicolumn{2}{|c|}{ Fabric HB50 ROLL 401184C } & $\begin{array}{c}\text { Fabric HB26 ROLL } \\
401400 B\end{array}$ \\
\hline $\mathrm{SiC}$ & $\mathrm{Al}_{2} \mathrm{O}_{3}$. & $\mathrm{Al}_{2} \mathrm{O}_{3}$. \\
\hline \multicolumn{3}{|c|}{ Average breaking load [N] } \\
\hline $19.2 \pm 1.8$ & $29 \pm 4.4$ & $61.4 \pm 5.9$ \\
\hline
\end{tabular}

Table 5. The test results of average breaking load of adhesive bonding of polyethylene fabrics to ceramics by means of Poxipol adhesive

\begin{tabular}{|c|c||}
\hline \multicolumn{2}{|c||}{ Poxipol adhesive } \\
\hline Fabric HB50 ROLL 401184C & Fabric HB26 ROLL 401400B \\
\hline \multicolumn{2}{|c||}{$\mathrm{Al}_{2} \mathrm{O}_{3}$. } \\
\hline \multicolumn{2}{|c||}{ Average breaking load $[\mathrm{N}]$} \\
\hline $22.6 \pm 4.3$ & $47.1 \pm 3.5$ \\
\hline
\end{tabular}

The specimens were fixed in the grips of the strength testing machine (Fig. 10) and loaded at the speed of $10 \mathrm{~mm} / \mathrm{min}$. This way of loading caused peeling the fabric off the ceramics.

In the process of adhesive bonding, the ceramic plates were rinsed with isopropyl alcohol and wiped with a cotton cloth until there were no marks on the clean material. The $\mathrm{Al}_{2} \mathrm{O}_{3}$ ceramics, which was covered with a pink film, needed more thorough rinsing. Due to the hardness of the used ceramics, it was not possible to make the bonded surface rough. The surfaces of the fabrics before bonding were also wiped with a cotton cloth soaked in alcohol. The strength of the specimens of Type 1 (1) was tested on the Louis Shopper strength testing machine, designed for testing fabrics. The strength of the remaining specimens was examined in the Hung Ta HT-2402 strength testing machine.

In the event of a sufficient repetition of the experiment results, they were calculated statistically by determining the confidence interval for the significance level of $1-\alpha=0.95$.

\subsubsection{Specimens no 2}

Polyethylene square-shaped fabrics, with length sides equalling $20 \mathrm{~mm}$, were placed in between the front surfaces of the specimens, which were $16 \mathrm{~mm}$ in diameter. It was impossible to measure the strength of the specimens bonded with Bondicx $01 \mathrm{CX} 80$, since they were destroyed through the fabric layer while trying to fix them in the strength testing machine, with forces of $3.5 \mathrm{~N}-$ Fig. 11.

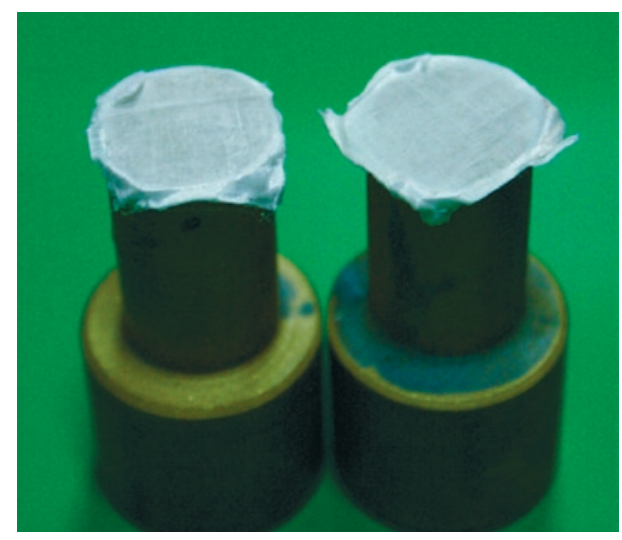

Fig. 11. An example of fabric delamination during an attempt to fix the specimen in the grips of the strength testing machine

Therefore, it was decided to resign from bonded polyethylene fabrics and in the tested butt joints polyethylene foil spacers was used, $0.2 \mathrm{~mm}$ thick. Before bonding, the foil was washed with alcohol. The test results are presented in Table 6.

On the basis of the investigation, it was discovered that polyethylene as a thermoplastic component is characterised with low adhesive properties (for instance using a cotton cloth instead of polyethylene, in the test, caused that the strength of the Bondicx 01 adhesive based specimens was increased by over 2.5 times). Thus, the adhesive joints of the polyethylene demonstrate low strength, and the destruction of such joints is typically adhesive in its character. This type of damage occurred in all the cases of the butt joint specimens with polyethylene spacers. Among the tested adhesives, Scotch-Weld 8010 proved to be the most suitable for bonding polyethylene.

\subsection{Results and discussion}

\subsubsection{Specimens no 1}

In all the cases, the joints were destroyed through separating the thin layer of the fabric (delamination and peeling off the thin layer which is adjacent to the ceramics) - Fig. 6 . It means that these fabrics are not fit for adhesive bonding since their tensile strength, perpendicularly to the alignment of the fibres, is low. Moreover, these fabrics cannot be oversaturated even with adhesives of increased fluidity, such as Bondicx 01 CX80. Higher strength of specimens prepared from the HB26 ROLL 401400B fabric resulted exclusively from increased interlayer strength of the fabric itself, and not its better adhesive properties.
Table 6. The test results of average breaking load of butt joints for various adhesives

\begin{tabular}{||c|c|c|c|c|c|c||}
\hline \multicolumn{7}{|c||}{ Adhesives } \\
\hline Bondicx 01 & Poxipol & Loctite3038 & $\begin{array}{c}\text { Scotch-Weld } \\
\mathbf{8 0 1 0}\end{array}$ & Black silicon & $\begin{array}{c}\text { Terostat } \\
\text { M9399 }\end{array}$ & $\begin{array}{c}\text { Bondicx 01 } \\
\text { (cotton linen) }\end{array}$ \\
\hline \multicolumn{7}{|c||}{ Average breaking load [N] } \\
\hline 657 & $945 \pm 49$ & $830 \pm 153$ & $1190 \pm 184$ & $124 \pm 21$ & $208 \pm 17$ & $1795 \pm 91$ \\
\hline \multicolumn{7}{|c|}{ Stresses [MPa] } \\
\hline 3.285 & $\begin{array}{c}4.725 \\
\pm 0.245\end{array}$ & $\begin{array}{c}4.15 \\
\pm 0.765\end{array}$ & $\begin{array}{c}5.95 \\
\pm 0.92\end{array}$ & $\begin{array}{c}0.62 \\
\pm 0.105\end{array}$ & $\begin{array}{c}1.04 \\
\pm 0.085\end{array}$ & $\begin{array}{c}8.975 \\
\pm 0.455\end{array}$ \\
\hline
\end{tabular}

Table 7. The test results of average breaking load of butt joints for various adhesives and Microflex fabric

\begin{tabular}{||c|c|c|c|c|c|c||}
\hline \multicolumn{7}{|c||}{ Adhesives } \\
\hline Bondix 01 & Poxipol & Loctite3038 & $\begin{array}{c}\text { Scotch-Weld } \\
\mathbf{8 0 1 0}\end{array}$ & $\begin{array}{c}\text { Black } \\
\text { silocon }\end{array}$ & $\begin{array}{c}\text { Terostat } \\
\text { M9399 }\end{array}$ & $\begin{array}{c}\text { Epidian 57/ } \\
\text { Z1 }\end{array}$ \\
\hline \multicolumn{7}{|c||}{ Average breaking load [N] } \\
\hline $1684 \pm 188$ & $2987 \pm 187$ & $0^{*}$ & 232 & $72.5 \pm 12$ & $295 \pm 28$ & $2018 \pm 185$ \\
\hline \multicolumn{7}{|c|}{ Stresses [MPa] } \\
\hline $8.38 \pm 0.94$ & $14.86 \pm 0.93$ & $0^{*}$ & 1.15 & $0.36 \pm 0.06$ & $1.48 \pm 0.14$ & $10.04 \pm 0.92$ \\
\hline
\end{tabular}


Table 8. Pull off strength of Bondicx 01 CX80 adhesives in joints with aramid fabrics

\begin{tabular}{||c|c|c|c|c||}
\hline \multicolumn{5}{|c||}{ BONDICX 01 adhesive } \\
\hline Fabric & Microflex & T 750 & CT 709 & XP S102 \\
\hline Average breaking load [N] & $1684 \pm 188$ & $1145 \pm 142$ & $1452 \pm 90$ & $101.2 \pm 6.9$ \\
\hline Pull off strength [MPa] & $8.38 \pm 0.94$ & $5.70 \pm 0.71$ & $7.22 \pm 0.45$ & $0.503 \pm 0.034$ \\
\hline
\end{tabular}

Table 9. Pull off strength of Poxipol adhesive in joints with aramid fabrics

\begin{tabular}{|c|c|c|c||}
\hline \multicolumn{4}{|c||}{ Poxipol adhesive } \\
\hline Fabric & Microflex & T 750 & CT 709 \\
\hline $\begin{array}{c}\text { Average breaking load } \\
{[\mathrm{N}]}\end{array}$ & $2987 \pm 187$ & $1466 \pm 140$ & $473.3 \pm 49.9$ \\
\hline \begin{tabular}{c} 
Pull off strength [MPa] \\
\hline
\end{tabular} & $14.86 \pm 0.93$ & $7.29 \pm 0.70$ & $2.35 \pm 0.25$ \\
\hline
\end{tabular}

The attempts to bond aramid fibres - XP S102, T750, Microflex and CT709 - were preceded with a preliminary experiment, where small pieces of the fabrics were covered with Epidian 57/Z adhesive in order to check whether these fabrics become oversaturated and whether the saturant demonstrated good adhesion to the fabrics. Out of the tested fabrics, it appeared that only Microflex fabric became thoroughly oversaturated. The T 750 fabric was characterised with the worst adhesive properties, as the curing adhesive practically was not bonded to the fabric. Therefore, the aramid fabric, Microflex type, was selected for the initial strength testing. The results of this phase of the investigation have been specified in Table 7 .

The conducted research proved that Loctite 3038 and Scotch Weld 8010 adhesives, designed to bond polyethylene are specialist adhesives and cannot be used for bonding aramid fabrics. The Loctite 3038 adhesive in contact with an aramid fabric and brass did not become cured within 24 hours, however when placed in a polyethylene syringe (remaining only in contact with polyethylene) it became cured at the same time. The investigation proved low pull off strength of silicone sealants - Black Silicone and Terostat M9399, which results both from poor adhesion to polyethylene and aramids and also their low cohesive strength. A characteristic feature of these adhesive components is their elasticity after curing.

In the further experimental test, the Bondicx 01 CX80 and Poxipol adhesives are used, since they were characterised with sufficiently high pull off strength in the bonding of Microflex fabric. The inves-

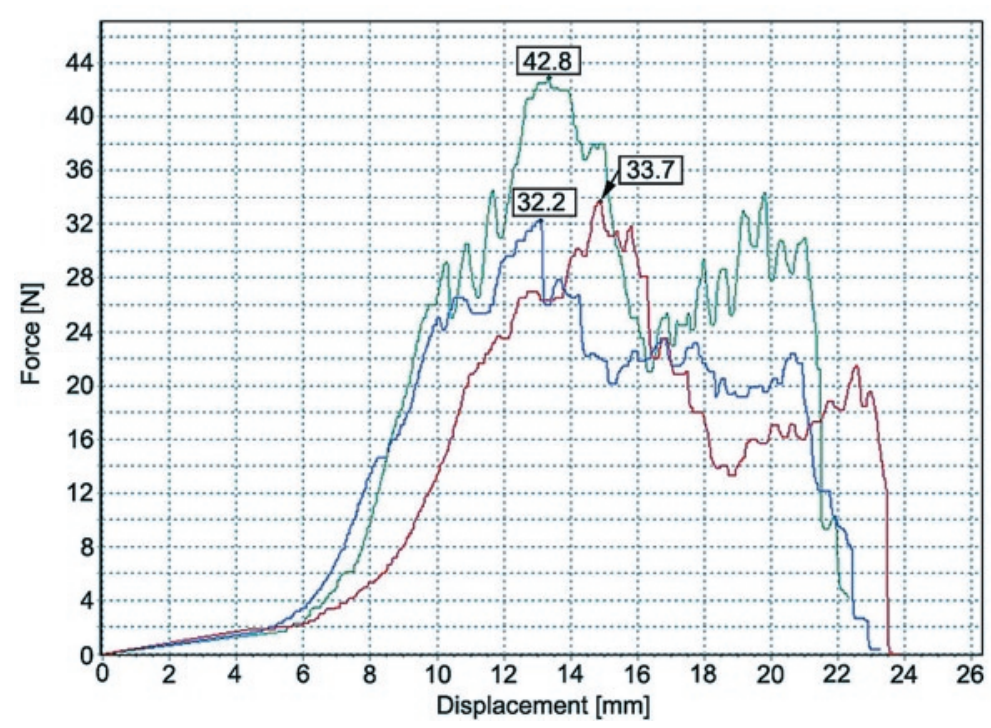

Fig. 12. Examples of three measurements of breaking load to separating Microflex from $\mathrm{Al}_{2} \mathrm{O}_{3}$ ceramics, bonded with Bondicx 01 adhesive (the value of maximum forces equals 32, 43 and $34 \mathrm{~N}$ ) tigation results of this phase of the investigation have been specified in Tables 8 and 9 .

\subsubsection{Specimens no 3}

The aim of the conducted investigation was to check whether $\mathrm{Al}_{2} \mathrm{O}_{3}$ and $\mathrm{SiC}$ ceramics are characterised with comparable adhesive properties. Specimens no 3 were face-bonded through one layer of Microflex fabric with Bondicx and Poxipol adhesives. The investigation results are specified in Table 10.

Table 10. Comparison of specimens no 3 pull off strength, prepared on the basis of SiC and $\mathrm{Al}_{2} \mathrm{O}_{3}$ ceramics (Microflex fabric)

\begin{tabular}{||c|c|c|c||}
\hline \hline \multicolumn{2}{||c||}{ Bondicx 01 CX80 adhesive } & \multicolumn{2}{c||}{ Poxipol adhesive } \\
\hline $\mathrm{SiC}$ & $\mathrm{Al}_{2} \mathrm{O}_{3}$ & $\mathrm{SiC}$ & $\mathrm{Al}_{2} \mathrm{O}_{3}$ \\
\hline \multicolumn{4}{|c||}{ Breaking load [N] } \\
\hline $2522.5^{*}$ & $1994 \pm 540$ & $1860 \pm 91$ & $2585 \pm 548$ \\
\hline \multicolumn{4}{|c|}{ Stresses [MPa] $\left(\mathrm{A}=346.4 \mathrm{~mm}^{2}\right)$} \\
\hline 7.28 & $5.76 \pm 1.56$ & $5.37 \pm 0.27$ & $7.46 \pm 1.58$ \\
\hline
\end{tabular}

*- Destruction of four out of five tested samples occurred on the surface between a steel sample and SiC ceramics, bonded with Epidian 57/Z1. Thus, the strength was measured on the basis of two highest values of the breaking load.

Table 11. Peel off strength of adhesive joints which bond Microflex fabric to ceramics

\begin{tabular}{||c|c|c|c||}
\hline \hline \multicolumn{1}{|c|}{ Bondicx 01 adhesive } & Poxipol adhesive \\
\hline SiC & $\mathbf{A l}_{\cdot} \mathbf{0}_{\mathbf{3}}$ & $\mathbf{S i C}$ & $\mathbf{A l}_{\cdot 2} \mathbf{O}_{\mathbf{3}}$ \\
\hline \multicolumn{4}{|c||}{ Maximum breaking load [N] } \\
\hline $34.75 \pm 10.31$ & $34.22 \pm 5.38$ & $18.8 \pm 1.62$ & $24.2 \pm 4.6$ \\
\hline \multicolumn{4}{|c||}{ Peel off strength [N/mm] } \\
\hline $1,96 \pm 0,56$ & $1,95 \pm 0,31$ & $1,07 \pm 0.09$ & $1,38 \pm 0,26$ \\
\hline
\end{tabular}

The Bondicx 01 CX80 adhesive demonstrated better adhesion to $\mathrm{SiC}$ ceramics, whereas Poxipol adhesive to $\mathrm{Al}_{2} \mathrm{O}_{3}$ ceramics. It was also proved that Epidian 57/Z1 epoxy adhesive was characterised by better adhesion to $\mathrm{Al}_{2} \mathrm{O}_{3}$ ceramics.

\subsubsection{Specimens no 4}

The investigation conducted with specimens no 4 concerned ceramics $\mathrm{SiC}$ and $\mathrm{Al}_{2} \mathrm{O}_{3}$ as well as Microflex fabric and two adhesives: Bondicx 01 and Poxipol. As the adhesive layers of joints were loaded to peel off, the changing forces in the function of displacement the cross beam of strength testing machine was registered (Fig. 12) and the values of maximum forces obtained in the attempts are compared. The investigation results have been listed in Table 11.

The joints where Bondicx 01 adhesive was used, regardless of the type of ceramics, were characterised with heightened strength, as compared to joints formed on the basis of Poxipol adhesive.

\section{Conclusions}

1. The batches of loose aramid fabrics are characterised with higher ballistic resistance compared to polymer composites made with such fabrics and multilayered composites, built up of thin metal layers and aramid fabrics. 
5. Ceramic layers considerably raise ballistic resistance of shields. It seems that their exploitation in such shields is necessary.

6. The tested polyethylene fabrics and the aramid fabric XPS102 cannot be used in adhesive bonding with ceramic plates due to their structure (they consist of thin layers of the material, which is poorly connected), resulting in delamination of the fabrics with low extending loads, perpendicularly to their surface, and inability to oversaturate.

7. The highest pull off strength (14 MPa) was achieved by joining the Microflex fabric with a metal specimen by Poxipol adhesive.
8. It appears that among all the tested specimens, specimens no 4 best reflect loading of ceramic plates, bonded to the fabrics, which are used to manufacture of bulletproof jacket. The research into such specimens indicated that, out of the two examined adhesives, Bondicx 01 adhesive is better suited for such applications than the Poxipol epoxy adhesive.

9. Adhesive bonding of ceramic plates between two thin sheets of aluminium alloy, and not joining them directly with aramid fabrics, in the event of a bullet impact, ensures the destruction of a small area of the ceramic layer, thus decreasing the protective properties of the shield to a small extent.

\title{
References
}

1. Cegła M. Habaj W, Podgórzak P. Development of Lightweight Bulletproof Vest Inserts with Increased Protection Capability. Problemy Mechatroniki 2014; 5(17): 23-33.

2. Dekel E, Rosenberg Z. Terminal Ballistics. Berlin Heidelberg: Springer-Verlag, 2012.

3. Formanek B, Jóźwiak S. Szczucka-Lasota B, Dolata-Groszc A, Bojar Z. Intermetallic alloys with oxide particles and technological concept for high loaded materials. Journal of Materials Processing Technology 2005; 162: 46-51, https://doi.org/10.1016/j.jmatprotec.2005.02.015.

4. Grujicic M, Bell W C, Pandurangan B. Design and material selection guidelines and strategies for transparent armour systems. Materials and Design 2012; 34: 808-819, https://doi.org/10.1016/j.matdes.2011.07.007.

5. Grujicic M, Pandurangan B, D'entremont B. The role of adhesive in the ballistic/structural performance of ceramic/polymer-matrix composite hybrid armor. Materials and Design 2012; 41: 380-393, https://doi.org/10.1016/j.matdes.2012.05.023.

6. Hazell P J. Ceramic Armour: Design and Defeat Mechanisms.Canberra:Argos Press, 2006.

7. López-Puente J,Arias A, Zaera R, Navarro C. The effect of the thickness of the adhesive layer on the ballistic limit of ceramic/metal armours. An experimental and numerical study. International Journal of Impact Engineering2005; 32(1-4): 321-336, https://doi.org/10.1016/j. ijimpeng.2005.07.014.

8. Senderski J, Płonka B, Wiśniewski A, Witkowski Z.Multilayer metal-ceramic passive amour for helicopters and special vehicles. Problemy Techniki Uzbrojenia 2011; 40: 57-64.

9. Wiśniewski A. Armours - construction, design and testing.Warsaw: WNT, 2001.

10. Yong M, Iannucci L, Falzon B G. Efficient modelling and optimisation of hybrid multilayered plates subject to ballistic impact. International Journal of Impact Engineering 2010; 37: 605-624, https://doi.org/10.1016/j.ijimpeng.2009.07.004.

\section{Jan GODZIMIRSKI \\ Marek ROŚKOWICZ}

Faculty of Mechatronics and Aerospace

Military University of Technology

ul. S. Kaliskiego 2, 00-908 Warsaw, Poland

\author{
Andrzej KOMOREK \\ Department of Aviation \\ Polish Air Force Academy \\ ul. Dywizjonu 303 35, 08-521 Dęblin, Poland
}

Emails: jan.godzimirski@wat.edu.pl,marek.roskowicz@wat.edu.pl, a.komorek@wsosp.pl 